\title{
Spatial heterogeneity in the structure of the planktonic food web in the North Sea
}

\author{
Katherine Richardson ${ }^{1, *}$, Torkel Gissel Nielsen ${ }^{2}$, Flemming Bo Pedersen ${ }^{3}$, \\ Jens Peter Heilmann ${ }^{1}$, Bo Løkkegaard ${ }^{4}$, Hanne Kaas ${ }^{2}$ \\ 'Danish Institute for Fisheries Research, Department of Marine and Coastal Ecology, Kavalergården 6, \\ DK-2920 Charlottenlund, Denmark \\ ${ }^{2}$ National Environmental Research Institute, Department of Marine Ecology and Microbiology, Frederiksborgvej 399, \\ PO Box 358, DK-4000 Roskilde, Denmark \\ ${ }^{3}$ ISVA, The Technical University of Denmark, Building 115, DK-2800 Lyngby, Denmark \\ ${ }^{4}$ DIS, Vestergade 7, DK-1456 Copenhagen K, Denmark
}

\begin{abstract}
The distributions of bacteria, phytoplankton, protozooplankton and copepod biomass and activity were examined in relation to hydrographic characteristics of the water column on 2 cruises in the North Sea (August 1991 and May 1992). On both cruises, the greatest phytoplankton biomass concentrations were associated with subsurface chlorophyll peaks. The $480: 665 \mathrm{~nm}$ absorption ratio suggested that phytoplankton located in surface waters were nutrient depleted and the ratio of phytoplankton carbon to bacterial carbon was generally low, suggesting that bacteria played an important role in nutrient turnover in surface waters at these times. In the subsurface chlorophyll pcaks, the pattern was variable with respect to the apparent nutrient status of the phytoplankton and the phytoplankton to bacteria carbon ratios. On the basis of oceanographic features, we identified sites where we predicted the formation of subsurface chlorophyll peaks. At these sites, the phytoplankton to bacteria carbon ratios in the subsurface peak were generally high and the 480:665 nm absorption ratio suggested that the phytoplankton were not nutrient limited. Also at these sites, the greatest absolute values of copepod production as well as the greatest percentage of total water column primary production being channelled into copepods were recorded. The regions where subsurface phytoplankton peaks were predicted to form were, thus, characterised by a 'classical' food web in which energy is efficiently transferred into larger zooplankters. We argue that heterogeneity in the nutrient status of phytoplankton in the subsurface peak can be important in controlling the type ('classical' or 'regenerated') of planktonic food web found in the water column as a whole.
\end{abstract}

KEY WORDS: Phytoplankton Zooplankton Food web Vertical and horizontal heterogeneity

\section{INTRODUCTION}

Phytoplankton are well known to be patchily distributed both in the horizontal and vertical planes in stratified marine waters. With respect to the horizontal, numerous studies have, since the mid-1970s, been devoted to describing the distribution of phytoplankton in relation to hydrographic fronts in temperate shelf seas (e.g. Holligan et al. 1984, Fogg et al. 1985,

\footnotetext{
- Present address: Dept Marine Ecology, Aarhus University, Finlandsgade 14, DK-8200 Aarhus N, Denmark.

E-mail: richardson@biology.aau.dk
}

Loder \& Platt 1985, Le Fèvre 1986, Richardson et al. 1986, Prieur \& Legendre 1988, Legendre \& Le Fèvre 1989). It has often been demonstrated that the occurrence of phytoplankton patches in frontal zones can influence the planktonic food web such that it, in the vicinity of the front, differs from that on either side of the frontal feature (e.g. Kiørboe \& Johansen 1986 , Kiørboe et al. 1988, Griffith et al. 1990, Munk \& Nielsen 1994).

Such observations have led to the suggestion (e.g. Cushing 1989, Kiørboe 1993) that the 'classical' food chain (characterized by large phytoplankton cells and a dominance of large zooplankton 'copepods') 
may dominate and that the production occurring in frontal waters may often have a higher $f$-ratio (i.e. percentage of new production relative to regenerated production sensu Dugdale \& Goering 1967) than in surrounding waters. If this is so, then these frontal regions may be particularly important in the transfer of energy to higher levels in the food web. There is circumstantial support for this hypothesis in the observation that fish larvae are often found to be concentrated in frontal regions (e.g. Munk et al. 1986, Kiørboe et al. 1988, Munk et al. 1995, and review by Heath 1992). Few studies have, however, actually examined the mechanisms that may give rise to heterogeneity in food web structure near frontal regions.

Vertical heterogeneity in phytoplankton distributions has also long been known to occur, and subsurface chlorophyll peaks are a common feature in stratified temperate marine waters (e.g. Petersson 1934, Holligan \& Harbour 1977, Vandevelde et al. 1987 , Riegman et al. 1990). However, it is only relatively recently that it has been demonstrated that these peaks are often comprised of actively photosynthesizing phytoplankton (e.g. Richardson 1985, Richardson \& Christoffersen 1991, Bjørnsen et al. 1993, Nielsen et al. 1993, Heilmann et al. 1994, Karlson et al. 1996). Photosynthesis occurring in these subsurface peaks can make a significant contribution to the total annual primary production occurring in a given region (Richardson \& Christoffersen 1991). In addition, several studies have demonstrated changes in the composition of and/or production in other components of the planktonic food web in association with subsurface phytoplankton peaks (e.g. Holligan et al. 1984, Nielsen et al. 1990, 1993, Munk \& Nielsen 1994). Thus, it seems clear that there is also the potential for vertical heterogeneity in the distribution and activity of plankton to significantly affect the overall production patterns in a given region.

The purpose of this study was to examine both horizontal and vertical heterogeneity in primary and secondary production in the central North Sea to try and identify the causes of such heterogeneity. The investigation has its starting point in studies over Dogger Bank (Nielsen et al. 1993) in which we identified the presence of a subsurface chlorophyll peak in the pycnocline layer and where we reported evidence which suggested that the structure of the planktonic food web associated with the subsurface chlorophyll peak changed with distance from the northern edge of the Bank.

After Nielsen et al. (1993) was reported, Bo Pedersen (1994) presented a model based partly on the hydrographic and chlorophyll data collected during that study and the August cruise data presented here. He argues that a bottom front occurs at the northern edge of the Dogger Bank and that a tidal 'pump' exists in association with this front that introduces nutrient-rich water into the pycnocline layer in a predictable manner associated with the spring-neap tidal cycle. Thus, assuming adequate light conditions in the pycnocline layer, this model predicts favorable conditions for phytoplankton growth and the creation of subsurface chlorophyll peaks on the stratified side of the front at specific periods in the tidal cycle.

In this study, we return to the Dogger Bank and the stratified waters to its north to (1) test the model (Bo Pedersen 1994) relating the formation of subsurface chlorophyll peaks north of the Dogger Bank to tidal phase (using data from the May 1992 cruise) and (2) examine whether the occurrence of sub-surface chlorophyll peaks can be linked to responses in the heterotrophic compartments of the plankton food web at a given site (using data from both cruises).

Specifically, we are testing the hypothesis that the 'classical' food chain will dominate in regions at or near where subsurface chlorophyll peaks are formed, while the 'microbial' food chain, characterized by protozooplankton grazers and relatively high bacteria to phytoplankton ratios, will dominate elsewhere.

\section{MATERIALS AND METHODS}

The data presented here were collected on 2 cruises with RV 'Dana' (Danish Food, Agriculture and Fisheries Ministry). The first cruise was carried out from 29 August to 5 September 1991 and stations near the Dogger Bank were visited. At this time, the front was at its outermost (spring tide) position. Hydrographic measurements made on this cruise have been reported and discussed in detail by Bo Pedersen (1994). On the second cruise (23 May to 1 June 1992), the stations on and near the Dogger Bank were revisited. At this time, the front was at its innermost (neap) position. In addition, a number of transects to the north and northeast of Dogger Bank were studied on this second cruise The study area and stations visited are shown in Fig. 1 Hydrographic measurements (CTD) were carried out at all stations. Chemical (nutrient) and plankton sampling were carried out at selected stations distributed along the transects.

Hydrographic and chemical measurements. Hydrographic measurements (temperature, salinity) were made using a Neil Brown CTD. Penetration of photosynthetically active radiation was measured at all daylight stations using a $Q$ Instruments (Copenhagen, Denmark) quanta meter (cosine collector) lowered through the water column and corrected for changes in surface irradiation. Inorganic nutrient analysis was carried out using an automated analyzer according to the methods of Grasshoff (1976). 

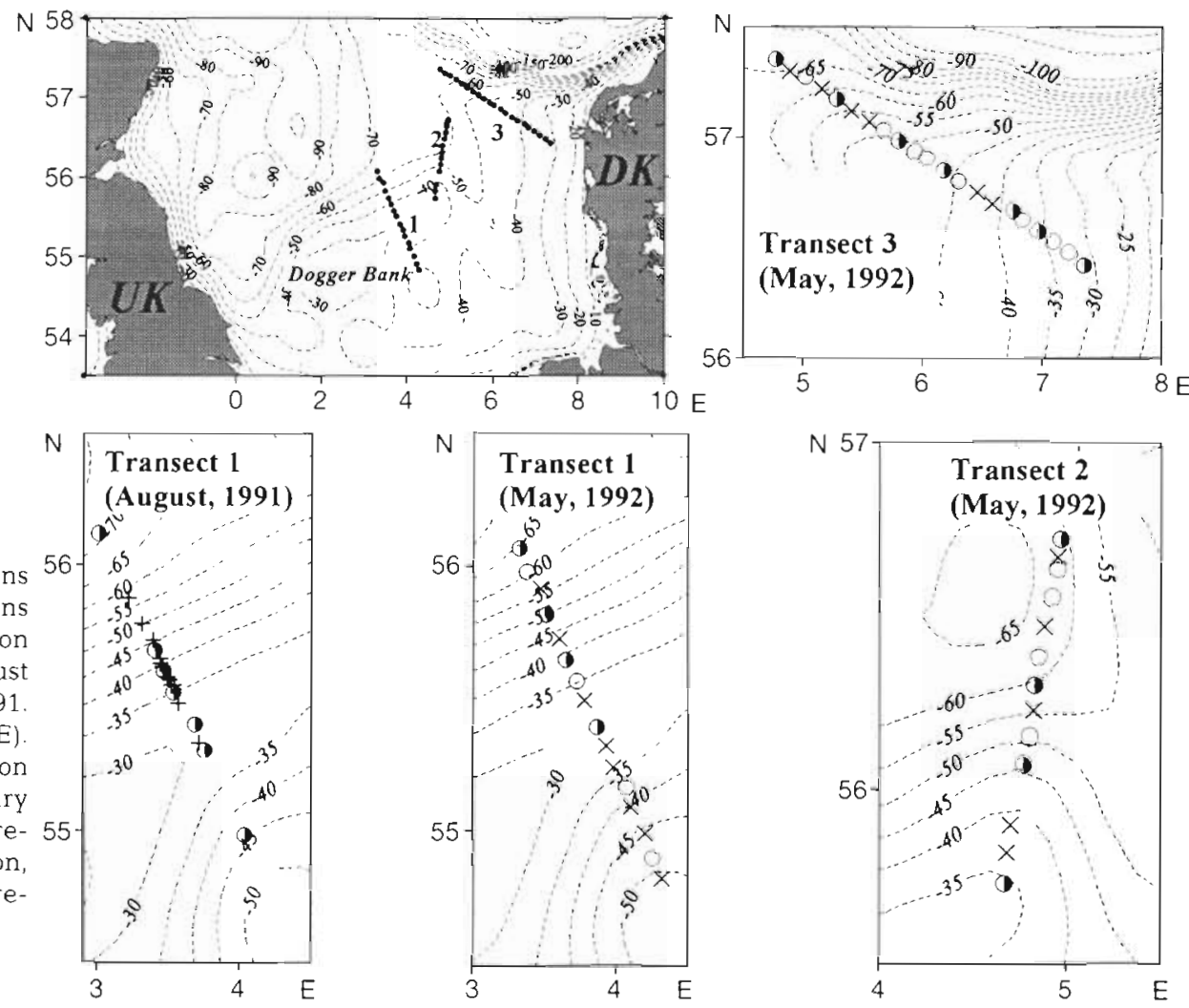

Fig. 1 Study area showing positions of the 3 transects and the stations visited in May 1992. A shorter version of Transect 1 was visited in Augus 1991 (end points August 1991 $55^{\circ} 18^{\prime} \mathrm{N}, 3^{\circ} 46^{\prime} \mathrm{E}$ and $56^{\circ} 8^{\prime} \mathrm{N}, 3^{\circ} 2^{\prime} \mathrm{E}$ ) $(\times)$ CTD and primary production measurements; (O) CTD, primary production and bacteria measure- 55 ments; (O) CTD, primary production bacteria and zooplankton measurements
Phytoplankton measurements. Fluorescence measurements were carried out using a $Q$ Instruments fluorometer (Hundahl \& Holck 1980). Fluorescence was converted to chlorophyll distribution in the water column by linear regressions constructed on the basis of discrete chlorophyll samples made at 2 to 3 different depths in the water column at all stations. Spectrophotometric determination of chlorophyll a (chl a) concentration was made following the Lorenzen method (Strickland \& Parsons 1972). Chlorophyll versus fluorescence linear regressions were obtained for each individual transect. The number of data points per transect varied between 13 and 55. All slopes were statistically significant $(p<0.005)$ and all $\mathrm{r}^{2}$ values $\geq 0.92$.

Sample collection for and measurement of primary production (using an artificial light incubator) were carried out as described in Nielsen et al. 1993. The photosynthetic characteristics alpha and $P_{\max }$ (photosynthetic efficiency and maximum photosynthesis) were determined in an artificial light incubator for a sample taken from the surface mixed layer $(3 \mathrm{~m})$ and from below the surface mixed layer (i.e. in the subsurface chlorophyll maximum). The obtained photosynthetic characteristics (corrected for in situ changes in chlorophyll concentration) were assumed to apply to the entire surface mixed layer and below the surface mixed layer, respectively.
Total watcr column primary production was calculated by applying the obtained photosynthesis characteristics (corrected for changes in chlorophyll throughout the water column) to a light versus depth (meter intervals) and time (hourly intervals) matrix constructed using measured light attenuation coefficients and a model describing average insolation rates over Copenhagen, which is at a latitude similar to that of most of our sampling stations (see Nielsen et al. 1993 for a more detailed description of the method).

'Subsurface chlorophyll' was defined as that found below the surface mixed layer (which was identified by a homogeneous distribution of sigma- $t$ (water density) in surface waters]. The depth of the maximal density gradient in the vertical varied along the different transects over a depth interval of 6 to $8 \mathrm{~m}$. These vertical density gradients were taken to represent the lower boundary of the surface mixed layer along each individual transect.

At some stations, the density profiles indicated the presence of more than one pycnocline. In such cases, the density profiles were compared to the fluorescence profiles. If no peak in fluorescence was observed at the most shallow pycnocline, then the next density gradient was examined, and so on. An abrupt increase in fluorescence at a density gradient was taken to represent a 'subsurface' chlorophyll layer. 
In cases where there was a distinct subsurface chlorophyll peak and fluorescence decreased to near background levels below the peak, 'subsurface' primary production was only calculated for the peak itself. In cases where elevated chlorophyll fluorescence was distributed throughout the bottom layer, subsurface primary production was calculated from the density gradient and down to a maximum of $50 \mathrm{~m}$. At stations where the total water column was mixed, the contribution of a 'subsurface' chlorophyll layer to total primary production was taken to be zero.

In addition to chlorophyll determinations at $665 \mathrm{~nm}$ on acetone extracted samples, the absorption at $480 \mathrm{~nm}$ was also determined. The 480:665 nm absorption ratio was then used as an indicator of the phytoplankton community's nutrient status, where ratios approaching and exceeding 2.0 suggest nutrient deficiency as described in Heath et al. (1990).

The conversion of chl a to phytoplankton carbon was made assuming a conversion factor for surface waters of $88 \mathrm{~g}$ phytoplankton $\mathrm{C}$ per $\mathrm{g}$ chl $\mathrm{a}$ and, for the subsurface chlorophyll laver: of $47 \mathrm{~g}$ phytoplankton $\mathrm{C}$ per $\mathrm{g}$ chl a (from Richardson et al, 1986). The difference between the 2 layers reflects an increase in chl a per cell in the low light adapted cells. As phytoplankton biomass in the water column was, at most stations, dominated by that found in the subsurface chlorophyll peak, an arbitrary conversion factor of $50 \mathrm{~g}$ phytoplankton $\mathrm{C}$ per $\mathrm{g}$ chlorophyll a was used when estimating water column phytoplankton carbon.

Bacteria and protozooplankton measurements. Samples for the determination of biomass and production of bacteria and protozooplankton were collected at 5 to 7 depths at the stations indicated in Fig. 1. Bacteria were quantified by the acridine orange technique (Hobbie et al. 1977). At least 400 cells were counted on each filter using an Olympus BH2 epifluorescence microscope. The volume was calculated from length and width measurements of at least 50 cells per filter and converted to carbon by a conversion factor of $0.35 \mathrm{pg} \mathrm{C}$ $\mu \mathrm{m}^{-3}$ (Bjørnsen 1986). Bacterial production was measured from incorporation of ${ }^{3} \mathrm{H}$-thymidine (Fuhrmann \& Azam 1980). Triplicate samples $(10 \mathrm{ml})$ were incubated with $5 \mathrm{nM}$ methyl- ${ }^{3} \mathrm{H}$ thymidine $\left(20 \mu \mathrm{Ci} \mathrm{nmol}{ }^{-1}\right.$, New England Nuclear) for $30 \mathrm{~min}$ at in situ temperature $\left(11^{\circ} \mathrm{C}\right)$. The biomass and production per $\mathrm{m}^{2}$ were calculated by trapezoidal integration over the depth strata (Nielsen \& Bresta 1984).

Blanks were prepared by the addition of formalin prior to the addition of the isotope. The incubations were stopped by the addition of buffered formalin $11 \%$ final concentration) and filtered onto $0.2 \mu \mathrm{m}$ cellulose nitrate filters. The filters were washed 10 times with $5 \%$ ice-cold TCA and counted by liquid scintillation counting. The incorporated ${ }^{3} \mathrm{H}$ thymidine was con- verted to cell production using a conversion factor of $1.1 \times 10^{18}$ cells $\mathrm{mol}^{-1}$ thymidine incorporated (Riemann et al. 1987).

The ratio of phytoplankton to bacterial carbon was used as an indicator of the relative importance of the 2 components of the food web at discrete depths in the water column. Ideally, in order to examine the relative importance of bacteria relative to phytoplankton, one should compare activity (production) of these 2 plankton groups. However, the fact that the subsurface chlorophyll maxima were found at different depths means that the light climate for these peaks differs. As the light climate is the major controlling factor for phytoplankton, considerable variability is noted in the phytoplankton production recorded in the subsurface peak (see Figs, 2 to 5 ).

We choose, therefore, to estimate the relative importance of phytoplankton and bacteria in the nutrient and energy turnover occurring both in surface waters and in the subsurface phytoplankton peaks by comparing the biomasses of the 2 groups. A low ratio, where harterial binmass is large relative to phytoplankton biomass, is assumed to indicate the potential presence of an active microbial food web.

Protozooplankton (ciliates and heterotrophic dinoflagellates) samples $(300 \mathrm{ml})$ were fixed in $1 \%$ Lugol's solution (final concentration) and counted after sedimentation ( $24 \mathrm{~h}$ ) using a Leitz inverted microscope. Identifications of ciliates to species or morphological types were based on Lynn \& Montagnes (1988). The thecate dinoflagellates were identified using Dodge (1985), while the athecate heterotrophic dinoflagellates were divided into size classes. Biovolumes were estimated from measurements of linear dimensions and assuming simple geometrical shapes. The biovolumes were converted to carbon using conversion factors of $0.11 \mathrm{pg} \mathrm{C} \mathrm{mm}^{-3}$ for ciliates and athecate dinoflagellates and $0.13 \mathrm{pg} \mathrm{C} \mathrm{m}^{-3}$ for thecate dinoflagellates (Edler 1979). The carbon demand and production of the protozooplankton were estimated by assuming a clearance rate of $10^{5}$ body volumes $\mathrm{h}^{-1}$ and a growth yield of 33\% (Hansen et al. 1997).

Copepod biomass and production. Mesozooplankton were sampled using a submersible pump (3000 ] min $^{-1}$ ) equipped with a $5 \mathrm{~m}$ conical net (mesh size $30 \mu \mathrm{m})$. During sampling, the pump was raised through the water column at $10 \mathrm{~m} \mathrm{~min}^{-1}$. The samples were fixed in buffered formalin $(2 \%$ final concentration). The sorting criteria used in later sample analysis are described in detail in Nielsen \& Sabatini (1996).

Egg production rates of the calanoid copepods were determined by incubation of fertilized females according to Kiørboe et al. (1985). The egg production rates of the egg carrying cyclopoid copepod Oithona spp. were calculated from the egg to female ratio in the biomass 
samples and the temperature dependent hatching rate (Nielsen \& Sabatini 1996). Data on the egg production and species composition of the copepod community are reported in detail elsewhere [1991 data in Munk \& Nielsen (1994); 1992 data in Nielsen \& Sabatini (1996)] but used here. The calculation of grazing impact was made from the specific egg production rate and the depth integrated biomass, assuming equal specific egg production and juvenile growth rate (Bergreen et al. 1988). For those species where no production estimates were available, the average specific egg production (excluding Oithona spp.) was applied. The carbon demand of the copepod community (i.e. ingestion) was estimated from the production rate assuming a gross efficiency of $33 \%$ (i.e ingestion $=3 \times$ production) (Hansen et al. 1997).

The copepod to protozooplankton biomass ratio in the water column is used here as an indicator of the relative importance of large relative to small zooplankters in the grazing activity taking place in the water column. When the ratio is high and large zooplankters (i.e. copepods) dominate the zooplankton community, the food web is assumed to be of a 'classical' type (sensu Cushing 1989).

\section{RESULTS}

The meteorological conditions (warm and calm) before and during our May 1992 cruise favoured the development of a very shallow pycnocline (Figs. 2a, 3a \& 4a). In addition, a layer of warm water was observed over the entire Dogger Bank transect at this time. Thus, evidence of the characteristic frontal water masses along the transect was not visible in surface measurements. The Dogger Bank transect examined on 29 to 30 August 1991 was studied much later in the heating period (Fig. 5a). As a result, the pycnocline is located much deeper in the water column and the thermocline layer $\left(8\right.$ to $16^{\circ} \mathrm{C}$ ) was thicker. A patch of colder water in the bottom waters south of the Dogger Bank indicates cross-transect water flow (Fig, 2a).

The low values of salinity recorded along the easternmost transect examined in May 1992 clearly reflect the influence of the Jutland Coastal Current here (i.e. region of freshwater influence) (Fig. 4b). The frontal structure in the salinity (abserved in the region of Stns 111 to 140 ) suggests a baraclinic circulation here driven by the density differences arising from the meeting of waters of different salinities.

The distributions of nitrate and chlorophyll, the ratio of $480: 665 \mathrm{~nm}$ absorption, bacterial biomass, and primary and bacterial production for each of the transects carried out on the 2 cruises are shown in Figs. 2 to 5 . Only in the deep bottom waters north of the Dogger
Bank and in the waters influenced by riverine inflow to the eastern North Sea were nitrate concentrations measurable.

A dominant feature on both cruises was the occurrence of subsurface chlorophyll peaks comprised of actively photosynthesizing phytoplankters. The greatest chlorophyll concentrations encountered on both cruises were recorded in subsurface peaks. Taking the study region as a whole, the chlorophyll concentrations recorded in the subsurface peak were often more than 4 times those observed at the surface, and concentrations of up to over $10 \mu \mathrm{g} \mathrm{l}^{-1}$ were observed in 1992.

Average estimated water column primary production (for all stations visited) was $414 \mathrm{mg} \mathrm{C} \mathrm{m}^{-2} \mathrm{~d}^{-1}$ ( $\mathrm{SD}=414, \mathrm{n}=7$ ) in August 1991 and $326 \mathrm{mg} \mathrm{C} \mathrm{m}^{-2} \mathrm{~d}^{-1}$ $(\mathrm{SD}=180, \mathrm{n}=44)$ in May 1992. The average integrated water column chlorophyll concentration observed in August 1991 was $36 \mathrm{mg} \mathrm{m}^{-2}$ ( $\mathrm{SD}=23.6, \mathrm{n}=25$ ) as compared with $34 \mathrm{mg} \mathrm{m}^{-2}(\mathrm{SD}=13, \mathrm{n}=130)$ in May 1992. The primary production associated with the subsurface peak accounted, at some stations, for up to about $75 \%$ and averaged 36 and $37 \%$ of the total primary production recorded, respectively, on the 1991 and 1992 cruises.

Average light attenuation coefficients (determinec according to the Lambert-Beer Law) for the 4 transects studied are shown in Table 1. These indicate the depth of $1 \%$ surface light penetration to be between 30 and $40 \mathrm{~m}$ over most of the study area. Using the $1 \%$ light penetration level as indicative of the extent of the photic zone, it appears that the subsurface chlorophyll peaks occur at the bottom of the photic zone while the elevated concentrations of nitrate observed in bottom waters north of the Dogger Bank seem to be below the photic zone. South of the Dogger Bank, the bottom depths are close to the predicted depth of the photic zone.

The 480:665 $\mathrm{nm}$ absorption ratios for surface and subsurface waters are shown together with chlorophyll distribution data in Figs. 2b, 3b, 4b \& 5b. In surface waters, the values are consistently high (usually over 2.0 ) indicating that the phytoplankton there are probably nutrient depleted. At depth, in the subsurface chlorophyll peaks, the ratio was generally, but not always, lower than for surface waters. The range of $480: 665 \mathrm{~nm}$ absorption ratios recorded in subsurface waters (from 1.2 to 2.7) suggests that the phytoplankton in some subsurface peaks were probably nutrient replete while, in others, they were not (Heath et al. 1990).

\section{Ratio of phytoplankton carbon to bacterial carbon}

The phytoplankton carbon:bacterial carbon ratios for the surface waters and in the subsurface chlorophyll peaks are presented along with the hydrographic tran- 

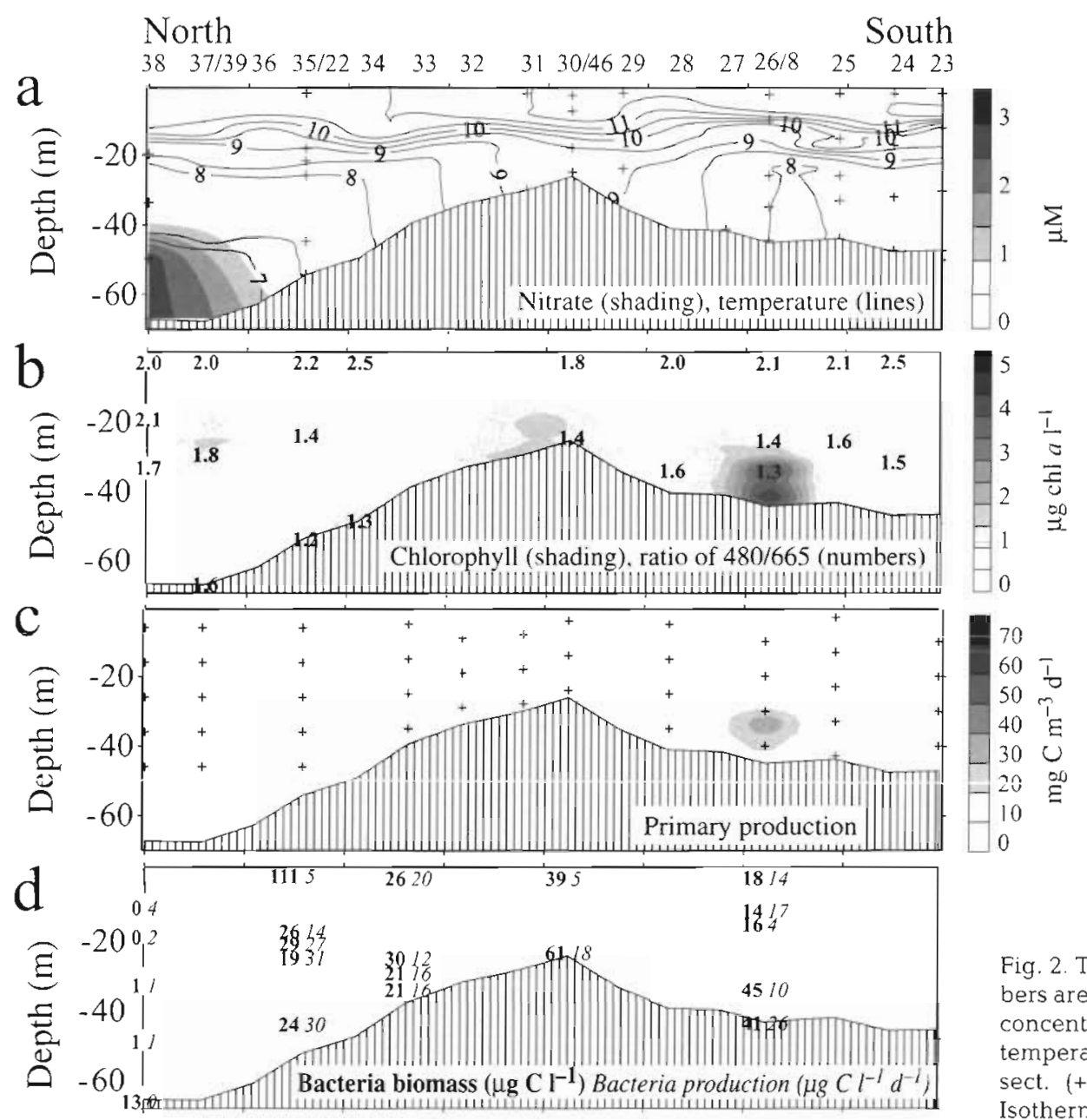

Fig. 2. Transect 1, May 1992 (station numbers are shown in upper panel): (a) Nitrate concentrations $\left(\mu \mathrm{mol} \mathrm{I}^{-1}\right)$ superimposed on temperature isotherms $\left({ }^{\circ} \mathrm{C}\right)$ along the transect. (+) Locations of nitrate sampling Isotherms drawn from temperature data collected with the CTD at every station. (b) Chlorophyll distributions ( $\mu \mathrm{g} \mathrm{l}^{-1}$ ) calculated from conversion of fluorescence profiles generated at each station. Superimposed on the chlorophyll distributions are the measured 480:665 $\mathrm{nm}$ absorption ratios (numerical values) (c) Primary production ( $\left.m g \mathrm{C} \mathrm{m}^{-3} \mathrm{~d}^{-1}\right)$. (+) Stations where primary production was determined (d) Bacteria biomass (bold numerical val-

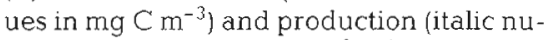
merical values in $\mathrm{mg} \mathrm{C} \mathrm{m} \mathrm{m}^{-3} \mathrm{~d}^{-1}$ ). (e) Phytoplankton:bacteria carbon ratio in surface waters and in the subsurface chlorophyll peak. (f) Copepod:protozooplankton biomass ratio in the water column

sect data in Figs, 2 to 5. The lowest ratios of phytoplankton carbon:bacterial carbon were recorded in the surface waters, suggesting an important role for bacteria in the turnover of nutrients and energy occurring here. The phytoplankton carbon:bacterial carbon ratios recorded in the subsurface chlorophyll peaks were much more variable than those recorded at the surface. Maxima in phytoplankton carbon:bacterial carbon were recorded in the subsurface chlorophyll peaks at the northern edge of the Dogger Bank on both Dogger Bank transects. The highest phytoplankton carbon: bacterial carbon ratios encountered were recorded in the subsurface chlorophyll peak encountered on Transect 2 (Stns 84 to 89) in May 1992.

Phytoplankton carbon:bacterial carbon ratios along transect 3 (eastern North Sea) were generally lowboth in the surface waters and at depth. The highest value encountered was in a subsurface peak at Stn 129 . 
It should be noted, however, that bacterial biomass was higher along this freshwater-influenced transect than on the other transects (Figs. 2 to 5). Other workers (Karlson et al. 1996) have also found high bacterial biomasses associated with the Jutland Coastal Current waters compared with surrounding water masses and argue that this may be the result of anthropogenic enrichment of these waters with nutrients or organic material. The fact that the planktonic food web in the riverine-influenced waters of Transect 3 may be partly fueled by exogenous nutrient sources means that a direct comparison of phytoplankton:bacterial carbon ratios on this transect and the more open North sea transects may not be meaningful.

\section{Plankton patchiness and food web structure}

The ratio of copepod carbon:protozooplankton carbon in the water column is presented together with the
Fig. 3. Transect 2, May 1992 (station numbers are shown in upper panel): (a) Nitrate concentrations ( $\left.\mathrm{umol} \mathrm{l}^{-1}\right)$ superimposed on temperature isotherms $\left({ }^{\circ} \mathrm{C}\right)$ along the transect. ( + ) Locations of nitrate sampling. (b) Chlorophyll distrubutions $\left(\mu \mathrm{g} \mathrm{l}^{-1}\right)$ calculated from conversion of fluorescence profiles generated at each station. Superimposed on the chlorophyll distributions are the measured 480:665 $\mathrm{nm}$ absorption ratios (numerical values). (c) Primary production $\left(\mathrm{mg} \mathrm{C} \mathrm{m}^{-3}\right.$ $\left.\mathrm{d}^{-1}\right) .(+)$ Stations where primary production was determined. (d) Bacterial biomass (bold numerical values in $\mathrm{mg} \mathrm{C} \mathrm{Cm}^{-3}$ ) and production (italic numerical values in $\mathrm{mg} \mathrm{C} \mathrm{m}^{-3} \mathrm{~d}^{-1}$ ). (e) Phytoplankton:bacteria carbon ratio in surface waters and in the subsurface chlorophyll peak. (f) Copepod:protozooplankton biomass ratio in the water column

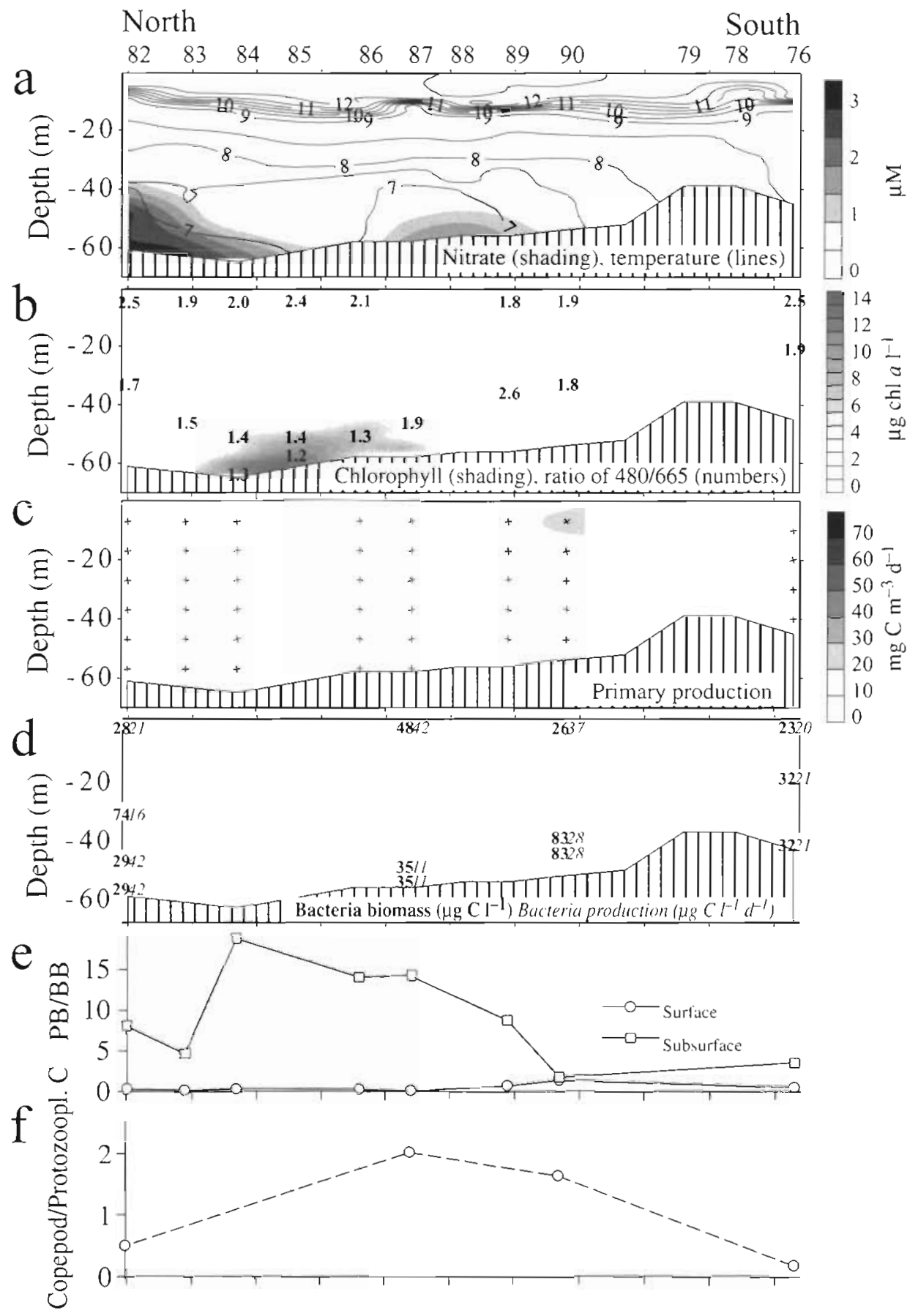




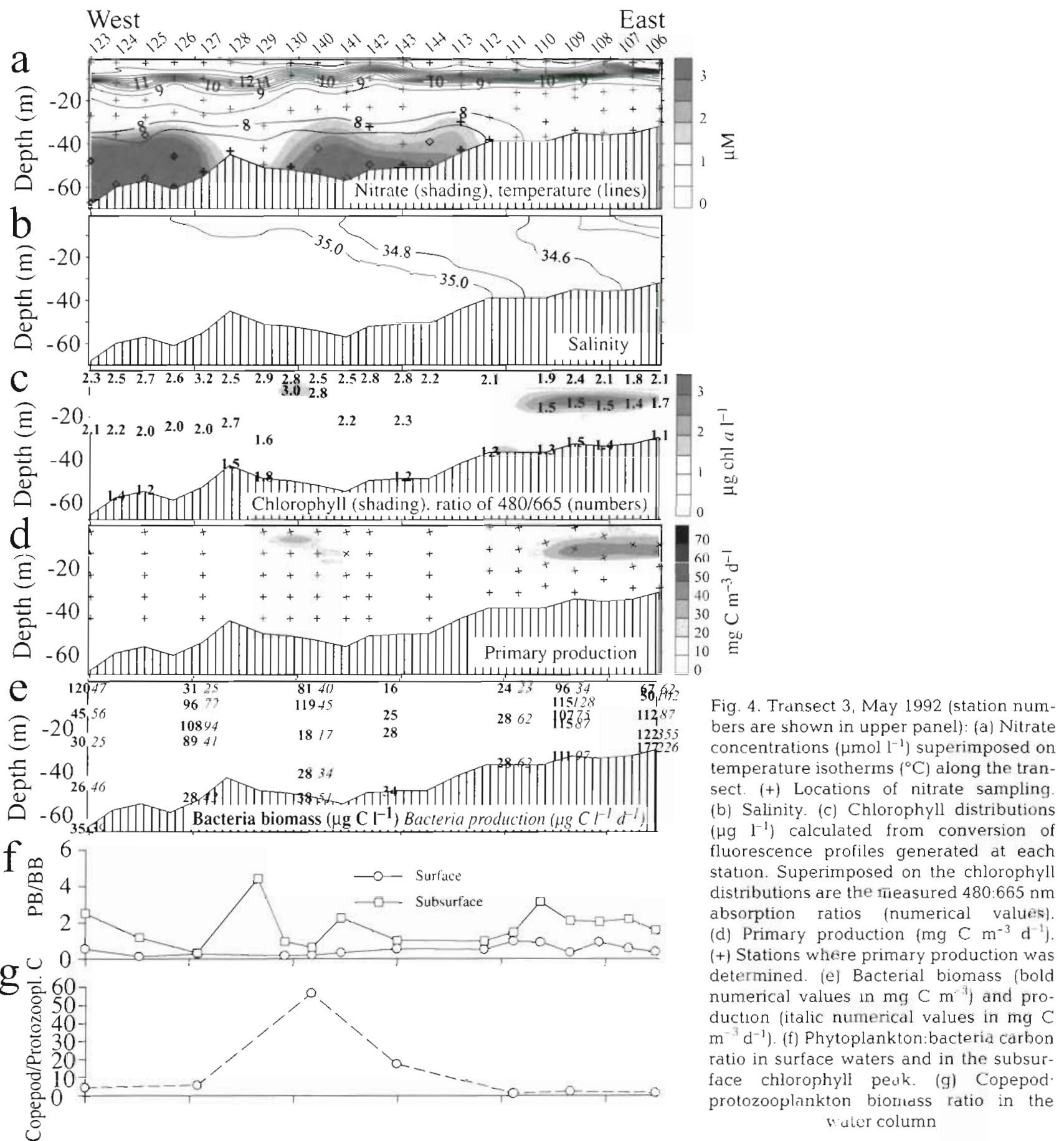

phytoplankton:bacterial carbon ratio recorded in the subsurface chlorophyll peak in Figs. 2, 3, 4 \& 5. There are fewer stations with copepod and protozooplankton. data than bacterial and phytoplankton data, and it is difficult to demonstrate a quantitative relationship between the 2 ratios. Nevertheless, the analysis shows that, even between closely spaced stations, there can be considerable variation in the importance of phyto- plankton relative to bacterial biomass in the subsurface chlorophyll peak, as well as in the copepod relative to protozooplankton biomass in the water column. There is also a tendency for both. ratios to peak in the same areas.

Carbon budgets in terms of biomass and production for the different plankton groups at all stations where plankton measurements were carried out are given 
in Tables 2 to 5. When comparing the absolute magnitude of the copepod ingestion and the percentage of phytoplankton production ingested by copepods at the different stations, several interesting features emerge:

(1) The absolute magnitude of copepod production (and, hence, ingestion) along the Dogger Bank transect. is very similar on both the August and May cruises.
(2) In the central North Sea (i.e. north of the Dogger Bank and away from the waters influenced by the Jutland Coastal Current, see Tables 2 to 4) copepod ingestion often appears to exceed primary production during the May cruise. As these copepods are observed to lay eggs, it is assumed they are actively feeding. These observations suggest that the copepods may be exploiting an energy source in addition to
Fig. 5. Transect 1, August 1991 (station numbers are shown in upper panel): (a) Nitrate concentrations ( $\mu \mathrm{mol}^{-1}$ ) superimposed on temperature isotherms $\left({ }^{\circ} \mathrm{C}\right)$ along the transect. $(+)$ Locations of sampling. (b) Chlorophyll distributions ( $\mu \mathrm{g} \mathrm{l}^{-1}$ ) calculated from conversion of fluorescence profiles generated at each station. Superimposed on the chlorophyll distributions are the measured $480: 665 \mathrm{~nm}$ absorption ratios (numerical values). (c) Primary production $\left(\mathrm{mg} \mathrm{C} \mathrm{m} \mathrm{m}^{-3} \mathrm{~d}^{-1}\right)$. (+) Stations where primary production was determined. (d) Bacterial biomass (bold numerical values in $\mathrm{mg} \mathrm{C} \mathrm{m}^{-3}$ ). (e) Phytoplankton:bacteria carbon ratio in surface waters and in the subsurface chlorophyll peak. (f) Copeod:protozooplankton biomass ratio in the water column
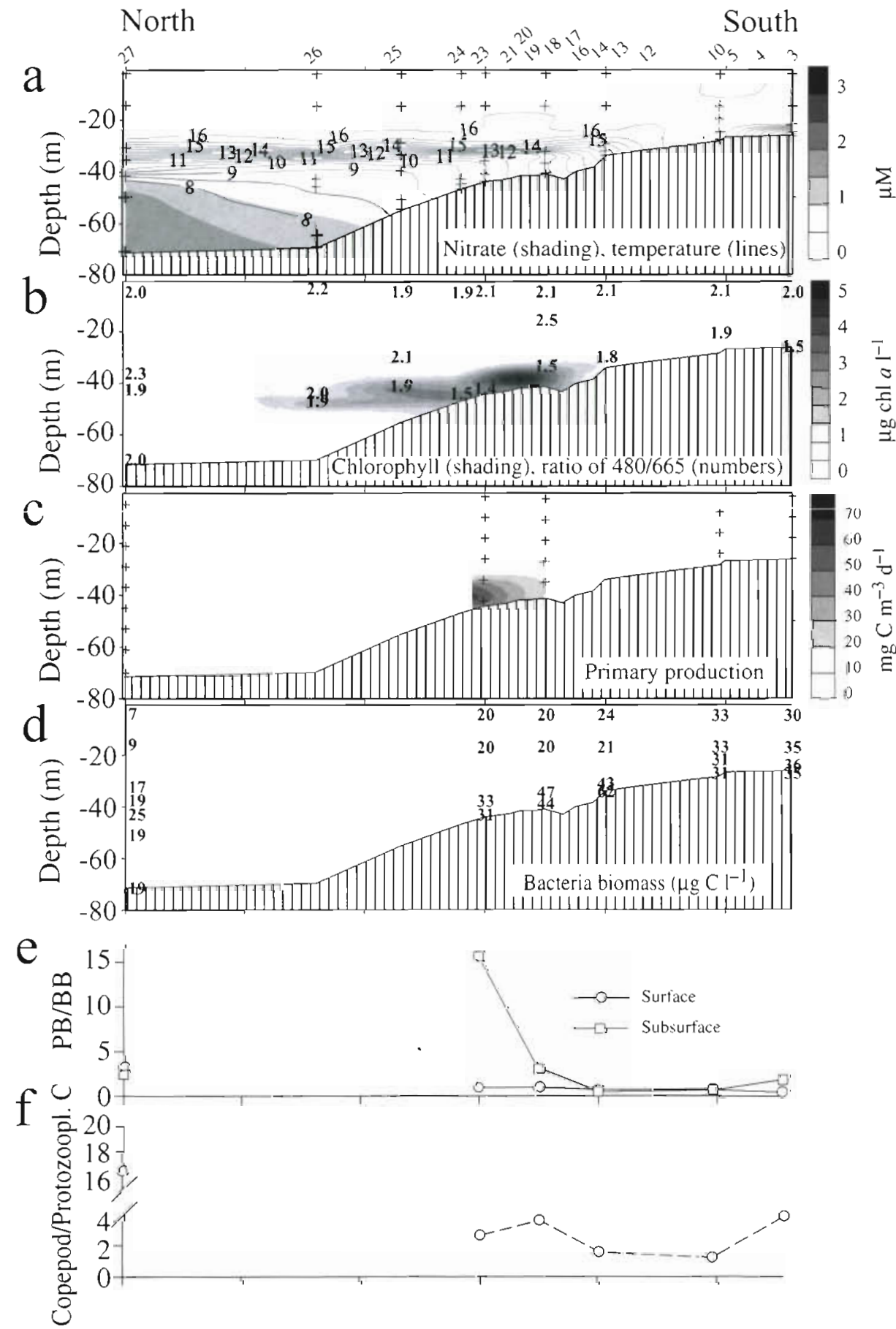
Table 1. Mean attenuation coefficients $(k)$ and mean water column depth $(m)$ at which $1 \%$ of the surface photosynthetic active radiation (SPAR) is left. SD is the standard deviation and $\mathrm{n}$ the number of observations

\begin{tabular}{|lcccrrr|}
\hline & Mean $k$ & SD & $\begin{array}{c}\text { Mean depth } \\
\text { at 1\% SPAR }\end{array}$ & SD & n \\
\hline Transect 1, Aug 1991 & 0.15 & 0.04 & 32 & 8 & 5 \\
Transect 2, May 1992 & 0.13 & 0.03 & 36 & 6 & 8 \\
Transect 3, May 1992 & 0.12 & 0.03 & 39 & 9 & 4 \\
Transect 1, May 1992 & 0.18 & 0.07 & 26 & 10 & 7 \\
\hline
\end{tabular}

phytoplankton or that primary production may be underestimated. Examination of the carbon budgets presented indicates that the calculated ingestion requirements of the copepods on most stations can be met by combining the primary and protozooplankton production. Thus, we suggest that copepods are grazing on both phyto- and protozooplankton. At only 1 station (87) does the combined phytoplankton and protozooplankton production not meet the calculated copepod grazing demand. At this station, there was an exceptionally dense patch of Calanus spp. recorded (see Table 3).

(3) At the most coastal stations (i.e. on and south of the Dogger Bank and at the easternmost stations of Transect 3: May 1992) the absolute magnitude of copepod ingestion as well as the \% of primary production being ingested by copepods is generally much lower than the values recorded in the offshore waters north of the Dogger Bank. This is probably a function of the distribution
Table 3. Distribution of biomass, production and ingestion of selected auto- and heterotrophs across Transect 2 (the central North Sea, May 27 to 28, 1992). Positions of the transect and stations shown in Figs. 1 \& 3 , respectively

\begin{tabular}{|c|c|c|c|c|}
\hline $\begin{array}{r}\text { Stn: } \\
\text { Bottom depth }(\mathrm{m}) \text { : }\end{array}$ & $\begin{array}{l}76 \\
42\end{array}$ & $\begin{array}{l}90 \\
55\end{array}$ & $\begin{array}{l}87 \\
57\end{array}$ & $\begin{array}{l}82 \\
60\end{array}$ \\
\hline \multicolumn{5}{|l|}{ Biomass $\left(\mathrm{mg} \mathrm{C} \mathrm{m}^{-2}\right)$} \\
\hline Phytoplankton & 1440 & 2060 & 2115 & 1865 \\
\hline Bacteria & 1166 & 2640 & 2278 & 2583 \\
\hline Heterotrophic ciliates & 253 & 476 & 940 & 395 \\
\hline Heterotrophic dinoflagellates & 184 & 131 & 241 & 110 \\
\hline Protozoans & 709 & 607 & 1181 & 509 \\
\hline Copepods & 1045 & 1622 & 4844 & 503 \\
\hline \multicolumn{5}{|l|}{ Production ( $\mathrm{mg} \mathrm{C} \mathrm{m} \mathrm{m}^{-2} \mathrm{~d}^{-1}$ ) } \\
\hline Phytoplankton & 245 & 574 & 235 & 244 \\
\hline Bacteria & 822 & 1429 & 1414 & 1360 \\
\hline Protozooplankton & 161 & 150 & 289 & 104 \\
\hline Copepods & 27 & 247 & 586 & 53 \\
\hline \multicolumn{5}{|l|}{ Ingestion ( $\left.\mathrm{mg} \mathrm{C} \mathrm{m}^{-2} \mathrm{~d}^{-1}\right)$} \\
\hline Protozooplankton & 486 & 455 & 876 & 316 \\
\hline Copepods & 80 & 74.0 & 1758 & 159 \\
\hline$\%$ primary production $\Rightarrow$ copepods & 33 & 129 & 748 & 65 \\
\hline
\end{tabular}

of Calanus spp. as these large copepods comprise only a small component of the total zooplankton biomass at stations less than about $40 \mathrm{~m}$ in depth (Fig. 6)

(4) On all 3 of the May 1992 transects, the greatest values of copepod production and ingestion were recorded at the plankton sampling stations that were located in or closest to the subsurface chlorophyll peaks occurring below $40 \mathrm{~m}$ in the water column (i.e. Stn 22 on Transect 1, Stn 87 on Transect 2, and Strn 140 on Transect 3).
Table 2. Distribution of biomass, production and ingestion of selected auto- and heterotrophs across Transect 1 (Dogger Bank, May 23 to 26, 1992). \% pnmary production $\Rightarrow$ copepods indicates $\%$ of primary production ingested by copepods. Positions of the transect and stations shown in Figs. 1 \& 2, respectively

\begin{tabular}{|c|c|c|c|c|c|}
\hline $\begin{array}{r}\text { Stn: } \\
\text { Bottom depth }(\mathrm{m}):\end{array}$ & $\begin{array}{r}8 \\
50\end{array}$ & $\begin{array}{l}46 \\
30\end{array}$ & $\begin{array}{l}33 \\
47\end{array}$ & $\begin{array}{l}22 \\
55\end{array}$ & $\begin{array}{l}38 \\
70\end{array}$ \\
\hline \multicolumn{6}{|l|}{ Biomass $\left(\mathrm{mg} \mathrm{C} \mathrm{m} \mathrm{m}^{-2}\right)$} \\
\hline Phytoplankton & 1200 & 735 & 1295 & 1700 & 1700 \\
\hline Bacteria & 1351 & 1236 & 935 & 1990 & 4861 \\
\hline Heterotrophic ciliates & & 587 & 123 & 1168 & 3505 \\
\hline Heterotrophic dinoflagellates & & 97 & 84 & 63 & 124 \\
\hline Protozoans & 684 & 207 & 1231 & 3629 & \\
\hline Copepods & 570 & 330 & 670 & 2100 & 1000 \\
\hline \multicolumn{6}{|l|}{ Production (mg $\mathrm{C} \mathrm{m}^{-2} \mathrm{~d}^{-1}$ ) } \\
\hline Phytoplankton & 280 & 385 & 412 & 348 & 176 \\
\hline Bacteria & 581 & 270 & 562 & 995 & 2097 \\
\hline Protozooplankton & & 111 & 38 & 251 & 582 \\
\hline Copepods & & 10 & 18 & 97 & 8 \\
\hline \multicolumn{6}{|l|}{ Ingestion ( $m g \mathrm{Cm}^{-2} \mathrm{~d}^{-1}$ ) } \\
\hline Protozooplankton & & 335 & 114 & 761 & 1763 \\
\hline Copepods & & 31 & 54 & 291 & 24 \\
\hline$\%$ primary production $\Rightarrow$ copepods & & 8 & 13 & 84 & 14 \\
\hline
\end{tabular}

\section{DISCUSSION}

\section{Plankton patchiness in relation to hydrography}

The density distributions recorded in August 1991 are typical of those predicted for shallow (sensu Pingree et al. 1978) bottom (sensu Bo Pedersen 1994) fronts where greatest density (temperature) gradients and, hence, the strongest baroclinic circulation are observed in the bottom layer Bo Pedersen (1994) presented evidence for a tidally driven 'pump' where nutrientrich bottom water from north of the Dogger Bank is transported into the (higher light) pycnocline regime in association with the front at the northern edge of the Dogger Bank. At the time of the August 1991 visit to the 
Table 4. Distribution of biomass, production and ingestion of selected auto- and Positions of the transect and stations shown in Figs. $1 \& 4$, respectively

\begin{tabular}{|c|c|c|c|c|c|c|c|}
\hline $\begin{array}{r}\text { Stn: } \\
\text { Bottom depth (m): }\end{array}$ & $\begin{array}{r}106 \\
30\end{array}$ & $\begin{array}{r}109 \\
32\end{array}$ & $\begin{array}{r}111 \\
38\end{array}$ & $\begin{array}{r}143 \\
55\end{array}$ & $\begin{array}{r}140 \\
60\end{array}$ & $\begin{array}{r}127 \\
53\end{array}$ & $\begin{array}{r}123 \\
62\end{array}$ \\
\hline \multicolumn{8}{|l|}{ Biomass $\left\{\mathrm{mg} \mathrm{Cm} \mathrm{m}^{-2}\right.$ ) } \\
\hline Phytoplankton & 1770 & 1995 & 2000 & 3000 & 2535 & 2710 & 2435 \\
\hline Bacteria & 3054 & 3492 & 1083 & 1278 & 2676 & 3398 & 2925 \\
\hline Heterotrophic ciliates & 344 & 174 & 359 & 13 & 4 & 56 & 64 \\
\hline Heterotrophic dinoflagellates & 63 & 45 & 224 & 38 & 48 & 77 & 183 \\
\hline Protozoans & 407 & 219 & 582 & 52 & 51 & 1.33 & 247 \\
\hline Copepods & 355 & 375 & 460 & 889 & 2908 & 710 & 1070 \\
\hline \multicolumn{8}{|l|}{ Production ( $\mathrm{mg} \mathrm{C} \mathrm{m}^{-2} \mathrm{~d}^{-1}$ ) } \\
\hline Phytoplankton & 595 & 664 & 245 & 403 & 152 & 172 & 256 \\
\hline Bacteria & 5006 & 2900 & 2108 & 1089 & 1780 & 2841 & 2806 \\
\hline Protozooplankton & 159 & 90 & 202 & 19 & 14 & 45 & 64 \\
\hline Copepods & 29 & 27 & 46 & 56 & 126 & 80 & 80 \\
\hline \multicolumn{8}{|l|}{ Ingestion ( $\mathrm{mg} \mathrm{C} \mathrm{m}^{-2} \mathrm{~d}^{-1}$ ) } \\
\hline Protozooplankton & 480 & 273 & 613 & 56 & 43 & 136 & 194 \\
\hline Copepods & 86 & 81 & 137 & 167 & 377 & 240 & 240 \\
\hline$\%$ primary production $\Rightarrow$ copepods & $5 \quad 14$ & 12 & 56 & 41 & 248 & 139 & 94 \\
\hline
\end{tabular}

Table 5. Distribution of biomass, production and ingestion of selected auto- and heterotrophs across Transect 1 (Dogger Bank, August 29 to 30, 1991). Positions of the transect and stations shown in Figs. $1 \& 5$, respectively

\begin{tabular}{|c|c|c|c|c|c|c|}
\hline $\begin{array}{r}\text { Stn: } \\
\text { Bottom depth }(\mathrm{m}) \text { : }\end{array}$ & $\begin{array}{r}3 \\
28\end{array}$ & $\begin{array}{r}5 \\
28\end{array}$ & $\begin{array}{l}13 \\
38\end{array}$ & $\begin{array}{l}18 \\
43\end{array}$ & $\begin{array}{l}23 \\
45\end{array}$ & $\begin{array}{l}27 \\
72\end{array}$ \\
\hline \multicolumn{7}{|l|}{ Biomass ( $\mathrm{mg} \mathrm{C} \mathrm{m}^{-2}$ ) } \\
\hline Phytoplankton & 580 & 185 & 570 & 1900 & 2430 & 3495 \\
\hline Bacteria & 864 & 902 & 1081 & 1263 & 1108 & 1127 \\
\hline Heterotrophic ciliates & 129 & 134 & 230 & 179 & 230 & 172 \\
\hline Heterotrophic dinoflagellates & 4 & 1 & 5 & 14 & 11 & 11 \\
\hline Protozoans & 1.33 & 135 & 235 & 193 & 241 & 183 \\
\hline Copepods & 505 & 157 & 358 & 686 & 630 & 3017 \\
\hline \multicolumn{7}{|l|}{ Production (mg C m-2 $\mathrm{d}^{-1}$ ) } \\
\hline $\begin{array}{l}\text { Phytoplankton } \\
\text { Bacteria }\end{array}$ & 213 & 223 & 249 & 430 & 1336 & 199 \\
\hline Protozooplankton & 18 & 6 & 23 & 56 & 869 & 59 \\
\hline Copepods & 14 & 7 & 12 & 18 & 14 & 50 \\
\hline \multicolumn{7}{|l|}{ Ingestion ( $\mathrm{mg} \mathrm{C} \mathrm{m}^{-2} \mathrm{~d}^{-1}$ ) } \\
\hline Protozooplankton & 55 & 18 & 71 & 170 & 260 & 178 \\
\hline Copepods & 41 & 19 & 37 & 53 & 42 & 151 \\
\hline$\%$ primary production $\Rightarrow$ copepods & 19 & 9 & 15 & 12 & $<1$ & 75 \\
\hline
\end{tabular}
heterotrophs across Transect 3 (the eastern North Sea, May 30 to June 1, 1992).

ducive to the rapid growth of phytoplankton. The observed subsurface chlorophyll peak in the pycnocline layer north of the Dogger Bank in August 1991 is consistent with this prediction (Fig. 5). Support for the predicted (Bo Pedersen 1994) baroclinic circulation pattern in bottom waters north of the Dogger Bank can also be found in the shape of the subsurface concentration profiles of nitrate, chlorophyll and primary production (Fig. 5).

The temperature distributions recorded south of the Dagger Bank in August 1991 resembled those north of the Bank. However, the distribution of the biological parameters was quite different. We believe that this is a result of the bottom depth being shallower to the south than to the north of the Dogger Bank. Light attenuation coefficients measured on this cruise indicated the level of $1 \%$ light penetration to be between 27 and $43 \mathrm{~m}$. Phytoplankton in the bottom layer of the water column can be expected to be mixed in this layer Thus: the average light experienced by the phytoplankton south of the Dogger Bank will be above $1 \%$ surface light levels. We believe this explains why no recordable nitrate concentrations were encountered here. We also predicted the presence of a baroclinic circulation pattern south of the Dogger Bank whereby bottom waters are transported along the bottom and into the pycnocline layer. However, as this transport does not result in the transfer of nutrient-rich bottom waters into the photic zone, its influence on the biology of the region is less marked than north of the Bank.

Dogger Bank transect, the front was at its spring tide position (i.e. full moon $+5 \mathrm{~d}$ ). In other words, the front was at its outermost offshore position. It is at this time that the maximum density gradients during the tidal cycle are observed in bottom water. Thus, it is also at this time that the Bo Pedersen (1994) model predicts maximum transport of nutrient-rich bottom water into the photic zone.

The model predicts ongoing transport of nutrientrich bottom water into the pycnocline layer starting with the beginning of the retreat of the front. Conditions in the pycnocline layer should, then, be con-
The situation along the Dogger Bank transect in May 1992 (Fig. 2) was markedly different from that recorded in August 1991. Firstly, the pycnocline was shallower and the thermocline layer thinner than that observed on the August cruise. These observations agree well with model predictions made by Bo Pedersen (1994) concerning pycnocline strength and depth based on considerations of seasonal variation in heat input, wind fields and tidal pumping. At the time of the May visit to the Dogger Bank transect, the weather was unusually warm and calm and a layer of warm (low density) water covered the entire area. This layer 


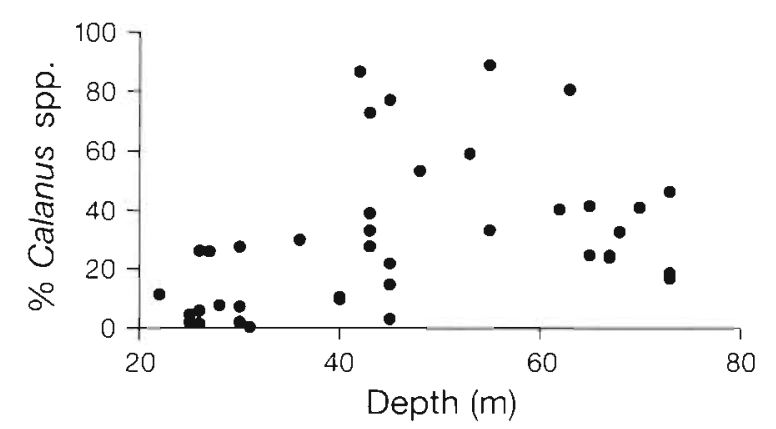

Fig. 6. Percentage of Calanus spp. contribution to total copepod biomass as a function of depth in May 1992 and August. 1991 cruises. Under the assumption of normal distribution of the probability parameter for Calanus spp., there is a significant difference in Calanus spp. contribution to copepod biomass below and above $40 \mathrm{~m}(<0.005$, paired $t$-test $)$

of water would have the effect of reducing the baroclinic circulation strength predicted for bottom waters. In addition, this May transect was made at full moon +8 to $9 \mathrm{~d}$ (= neap position of the front when it is at its innermost position), when there is minimal baroclinic circulation and transport of nutrient-rich bottom water to the photic zone. Thus, we predicted (and observed) a much weaker signal in the chlorophyll/primary production distributions in relation to the front at the northern edge of the Dogger Bank on this May cruise than was observed in August 1991.

The interactions between hydrographic and biological processes occurring on Transects 2 and 3 (May 1992) are more difficult to describe in detail than those occurring on the Dogger Bank transect. This is because the variations in bathymetry as well as tidal current speed and direction perpendicular to the Dogger Bank transect are small in comparison with the variation in these parameters perpendicular to the other 2 transects. Although the cross-transect flow is noted on the Dogger Bank transect, we predicted that it would be relatively small here, which allowed us to ignore crosstransect flow in the analysis of this transect.

Transect 2, on the other hand, lies near the end of the Dogger Bank. Thus, there are large lateral variations in bathymetry and tidal current speed and direction near this transect and we predicted significant crossfrontal flow. Transect 3 is located near the northeastern end of the Dogger Bank and, also, covers a number of underwater plateaus. As a result, there is significant variation in the bathymetry encountered here. In addition, this transect crosses the entrance to the German Bight, where we expect strong baroclinic circulation to compensate for warmer temperatures and freshwater input and where we know that the Jutland Coastal Current intermittently transports large quantities of water across the transect (Bolding Kristensen 1991).
Thus, we predicted greater cross-transect flow across these 2 transects than across the Dogger Bank transect. The distribution of the hydrographic parameters recorded on these transects confirms the existence of this cross-transect flow. Recognition of its existence prevents us from attempting the detailed analysis of the biologi$\mathrm{cal} /$ physical interactions occurring along these transects that we carried out for the Dogger Bank transect.

Nevertheless, both transects exhibit features relating to the subsurface chlorophyll peaks that we believe can be explained using arguments similar to those applied to the Dogger Bank transect. The subsurface chlorophyll peak observed on Transect 2 (Stns 83 to 87) exhibited the highest chlorophyll concentrations recorded on the entire cruise. We argue that this peak is formed in situ and is not the result of sedimentation from the upper layers of the water column. We base this argument on (1) the fact that the peak is very localized and we cannot envision a mechanism for such localized production in the surface waters, (2) the phytoplankton in the peak exhibit a lower $480: 665 \mathrm{~nm}$ ratio than those in the surface waters; this low ratio suggests nutrient replete phytoplankton that are not found in the surface waters and (3) the distribution of nitrate in the bottom waters indicates lower concentrations in association with the subsurface chlorophyll peak than in surrounding bottom waters, suggesting active nitrate utilisation at the site of the subsurface chlorophyll maximum.

We believe that the subsurface peak observed on Transect 2 occurred because of the bathymetry in this region of the North Sea. The peak occurred over a wide plateau to the north of the Dogger Bank. The plateau depth corresponds approximately to our predicted bottom depth of the photic zone. The relatively low depth over this plateau results in baroclinic circulation which persistently transports nutrients from the deeper regions north of the plateau onto the plateau and, ultimately, gives rise to the subsurface chlorophyll peak.

On Transect 3, subsurface chlorophyll peaks were clearly associated with the halocline-at the transition between freshwater-influenced coastal water and more open North Sea water and in bottom waters (i.e. Stns 128 to 140 ) associated with changes in bathymetry (shallower depth where nutrient-rich water is transported into the photic zone).

\section{Plankton patchiness and food web structure}

A problem in examining the effect of phytoplankton patchiness on the structure of the food web, in general, is the different sampling strategies adopted for different trophic levels. Chlorophyll (fluorescence) is measured with centimeter resolutions throughout the 
water column. The detailed picture that emerges is that large differences exist in the distribution and activity of phytoplankton in the water column. Copepods, on the other hand, are more difficult to relate to discrete depth layers as they, potentially, exploit the whole water column. Thus, copepod distributions and activities are, most often, recorded on a water column basis rather than at discrete depths in the water column. When relating phytoplankton and zooplankton activity, it is tempting to average the phytoplankton signal throughout the water column in order to make it directly comparable to the zooplankton signal. However, this would entail the loss of considerable detail in the signal and make it difficult to examine the effect of layers, per se, on the food web.

In this study, the highest concentrations (up to over $10 \mu \mathrm{g} \mathrm{l}^{-1}$ ) were observed in subsurface chlorophyll peaks and surface chlorophyll concentrations were generally less than $1 \mathrm{\mu g} \mathrm{I}^{-1}$. We argue, then, that it is the biomass of phytoplankton in the subsurface chlorophyll peaks that primarily influences the feeding response in the zooplankton and, thus, the water column response registered in the zooplankton. We choose, therefore, to examine characteristics of the zooplankton food web in the entire water column in relation to characteristics of the phytoplankton and bacteria in the subsurface peak.

The areas identified as those where we predicted the baroclinic transport of nutrients from bottom waters up into the photic zone (i.e. at the northern edge of the Dogger Bank, near Stns 84 to 87 on Transect 2 and in association with a bathymetric anomaly near Stns 128 to 140 on Transect 3 in May 1992) are those where the highest phytoplankton:bacterial carbon ratios in the subsurface chlorophyll peak are recorded. Also the 480:665 nm absorption ratios here indicate the presence of nutrient replete phytoplankton (Figs. 3 \& 4). In addition, the absolute magnitude of the copepod production and the \% of primary production being ingested by the copepods were greatest in these regions (Tables 3 \& 4). Thus, we argue that localized patches in which the 'classical' food web (characterized by the occurrence of many large zooplankter grazers) dominates will develop in the water column in association with the creation of subsurface chlorophyll peaks during summer months in the North Sea. These subsurface peaks will be generated by circulation phenomena through which nutrient-rich bottom water is transported into the photic zone.

Support for our argument comes from Munk \& Nielsen (1994) who have examined the distribution of fish larvae (i.e. grazers on large zooplankton) on our August 1991 Dogger Bank transect. These authors found the greatest biomass of fish larvae at the northern edge of the Dogger Bank [i.e. at the lacation where
Bo Pedersen (1994) predicts the development of a subsurface phytoplankton peak and in a region characterized by high phytoplankton:bacterial carbon and low 480:665 nm absorption ratios in the subsurface chlorophyll peak (Fig. 5)].

\section{Importance of heterogeneity in plankton distributions to the study area as a whole}

Both of the cruises carried out as part of this study took place during the period of thermal stratification of the central and northern North Sea, and, on both cruises, the greatest concentrations of phytoplankton biomass encountered were at depth in the water column. These subsurface phytoplankton accumulations were comprised of actively photosynthesizing phytoplankton. Despite the low ambient light conditions associated with these subsurface phytoplankton peaks, we estimate that the primary production associated with them was, on average, 36 to $37 \%$ of the total water column productivity at our sampling stations. At some stations, up to about $75 \%$ of total water column primary production was recorded in association with the subsurface chlorophyll peak.

We acknowledge that some of these estimates of photosynthetic rates in the subsurface chlorophyll peak may be too high, as both the surface and subsurface water samples were incubated in the same incubator (i.e. at the same temperature). In some cases, this means that the subsurface sample was incubated at up to $6^{\circ} \mathrm{C}$ higher than the collection temperature. This higher temperature of incubation can be expected to influence photosynthesis rates. The influence of temperature on phytoplankton growth rate exhibits a $Q_{10}$ of about 2 (Harris 1986). However, it has been demonstrated that temperature effects on photosynthesis are greatest on the maximum rate of photosynthesis $\left(P_{\max }\right)$. Alpha is relatively unaffected by temperature changes (Kirk 1984). As photosynthesis is light limited in these subsurface peaks, we expect the changes in temperature experienced by the phytoplankton from subsurface peaks under incubations to have only a small effect on the rates of photosynthesis estimated here for the subsurface peaks.

Thus, these subsurface phytoplankton peaks are capable of active photosynthesis. Their 480:665 nm ratios suggest that their physiological state is better than that of their surface water counterparts. Finally, the fact that the greatest biomass accumulations are found in the subsurface peaks makes these peaks especially important for grazers and we predict that they are primary sites for transferring of energy from primary to higher trophic levels during the period of thermal stratification in the North Sea (May to October, see Bo Pedersen 1994). 
We believe that the coupling between hydrographic and biological processes hypothesized by Bo Pedersen (1994) is a plausible explanation for the creation of these subsurface chlorophyll peaks along bottom fronts in the North Sea. The apparent mechanism of the stimulation of phytoplankton growth and accumulation at depth is the transport of nutrients from bottom water into the photic zone-this transport being caused by baroclinic circulation patterns occurring near the bottom front.

Our study suggests that, at the sites of formation of the subsurface chlorophyll peaks, a 'classical' food web dominated by large zooplankton grazers develops. Thus, we predict that regions where subsurface phytoplankton peaks are formed will be areas of efficient transfer of energy to higher trophic levels, and we expect accumulations of pelagic feeders (fish and larvae) in such areas.

Acknowledgements. The authors thank Alice Christoffersen and Jack Melbye for help in carrying out the biological measurements, Jacob Carstensen for help with the statistical analysis and the Captain and crew of RV 'Dana' for their help and support during data collection. This study was partially supported by a grant from the Danish Natural Science Research Council

\section{LITERATURE CITED}

Bergreen U, Hansen B, Kiørboe T (1988) Food size spectra, ingestion and growth of the copepod Acartia tonsa: implications for the determination of copepod production. Mar Biol 99:341-352

Bjørnsen PK (1986) Automatized determination of bacterioplankton biomass by image analysis. Appl Environ Microbiol 51:1199-1204

Bjornsen $P K$, Kaas $H$, Kaas $H$, Nielsen TG, Olesen $M$, Richardson K (1993) Dynamics of a subsurface phytoplankton maximum in the Skagerrak. Mar Ecol Prog Ser 95(3):279-294

Bolding Kristensen K (1991) The Jutland coastal current Technical University of Denmark. Series Paper no. 53, Lyngby

Bo Pedersen F (1994) The oceanographic and biological tidal cycle succession in shallow sea fronts in the North Sea and the English Channel. Estuar Coast Shelf Sci 38:249-269

Cushing DH (1989) A difference in structure between ecosystems in strongly stratified waters and in those that are only weakly stratified. J Plankton Res $11(1): 1-13$

Dodge JD (1985) Marine dinoflagellates of the British Isles Her Majesty's Stationery Office, London

Dugdale RC, Goering JJ (1967) Uptake of new and regenerated forms of nitrogen in primary productivity. Limnol Oceanogr 12:196-206

Edler L (1979) Recommendations for marine biological studies in the Baltic Sea. Baltic Mar Biol Publ 5:1-38

Fogg GE, Egan FRSB, Floodgate GD, Jones DA, Kassab JY, Lochte K, Rees EIS, Scrope-Howe S, Turley CM (1985) Biological studies in the vicinity of a shallow-sea tidal mixing front. VII. The frontal ecosystems. Phil Trans R Soc Lond Ser B 310:555-571
Fuhrman J, Azam F (1980) Bacterioplankton secondary production estimates for coastal waters of British Columbia, Antarctica and California. Appl Environ Microbiol 39(6): $1085-1095$

Grasshoff K (1976) Methods of seawater analysis. Verlag Chemie, Weinheim

Griffith PC, Douglas DJ, Wainright SC (1990) Metabolic activity of size-fractionated microbial plankton in estuarine, nearshore and continental shelf waters of Georgia. Mar Ecol Prog Ser 59(3):263-270

Hansen PJ, Bjornsen PK, Hansen B (1997) Zooplankton grazing and growth: scaling within the $2 \mu \mathrm{m}-2000 \mu \mathrm{m}$ body size range. Limnol Oceanogr 42:63-79

Harris GP (1986) Phytoplankton ecology: structure, function and fluctuation. Chapman and Hall, London

Heath MR (1992) Field investigations of the early life stages of marine fish. Adv Mar Biol 28:1-174

Heath MR, Richardson K, Kiørboe T (1990) Optical assessment of phytoplankton nutrient depletion. J Plankton Res 12(2):381-396

Heilmann JP, Richardson K, Ertebjerg G (1994) Annual distribution and activity of phytoplankton in the Skagerrak/Kattegat frontal region. Mar Ecol Prog Ser 112 $213-223$

Hobbie JE, Daley RJ, Jaspers S (1977) Use of nuclepore filters for counting bacteria by epifluorescence. Appl Environ Microbinl 33.122,5-122.8

Holligan PM, Harbour DS (1977) The vertical distribution and succession of phytoplankton in the western English Channel in 1975 and 1976. J Mar Biol Assoc UK 57(4): 1075-1093

Holligan PM, Harris RP, Newell RC, Harbour DS, Head RN, Linley EAS, Lucas MI, Tranter PRG, Weekley CM (1984) Vertical distribution and partitioning of organic carbon in mixed, frontal and stratified waters of the English Channel. Mar Ecol Prog Ser 14:111-127

Hundahl H, Holck $\mathrm{J}$ (1980) A new in situ fluorometer for detection of Rhodamine B and chlorophyll. Report no. 42 , Institute of Physical Oceanography, Univ of Copenhagen, p 145-154

Karlson B, Edler L, Granelli W, SahIsten E, Kuylerstierna M (1996) Subsurface chlorophyll maxima in the Skagerrakprocesses and plankton community structure. J Sea Res $35(1-3): 139-158$

Kiørboe T (1993) Turbulence, phytoplankton cell size, and the structure of pelagic food webs. Adv Mar Biol 29:1-72

Kiørboe $T_{1}$ Johansen K (1986) Studies of larval herring (Clupea harengus L.) patch in the Buchan area. IV. Zooplankton distribution and productivity in relation to hydrographic features. Dana 6:37-51

Kiørboe T, Møhlenberg F, Riisgård HU (1985) In situ feeding rates of planktonic copepods: a comparison of four methods. J Exp Mar Biol Ecol 88:67-81

Kiørboe T, Munk P, Richardson K, Christensen V, Paulsen H (1988) Plankton dynamics and larval herring growth, drift and survival in a frontal area. Mar Ecol Prog Ser 44: $205-219$

Kirk JTO (1984) Light and photosynthesis in aquatic ecosystems. Cambridge University Press, Cambridge

Le Fèvre J (1986) Aspects of the biology of frontal systems. Adv Mar Biol 23:210-299

Legendre L, Le Fèvre J (1989) Hydrodynamical singularities as controls of recycled versus export production in oceans. In: Berger WH, Smetacek VS, Wefer G (eds) Productivity of the ocean: present and past. John Wiley and Sons, Chichester, p 44-63

Loder JW, Platt T (1985) Physical controls on phytoplankton production at tidal fronts. In: Gibhs PE (ed) Proc 19th Eur 
Mar Biol Symp. Cambridge University Press, Cambridge, p 3-22

Lynn DH, Montagnes DJS (1988) Taxonomic descriptions of some conspicuous species of strobilidiine ciliates (Ciliophora: Choreotrichida) from the Isles of Shoals, Gulf of Maine. J Mar Biol Assoc UK 68:639-658

Munk P, Christensen V, Paulsen $H$ (1986) Studies of a larval herring (Clupea harengus L.) patch in the Buchan area. II. Growth, mortality and drift of larvae. Dana 6:11-24

Munk P, Larsson PO, Danielsen DS, Moksness E (1995) Larval and small juvenile cod Gadus morhua concentration in the highly productive areas of a shelf break front. Mar Ecol Prog Ser 125:21-30

Munk P, Nielsen TG (1994) Trophodynamics of the plankton community at Dogger Bank: predatory impact by larval fish. J Plankton Res 16(9):1225-1245

Nielsen G£, Bresta AM (1984) Guidelines for measurements of phytoplankton primary production. Baltic Mar Biol Publ $1: 1-23$

Nielsen TG, Kiørboe T, Bjørnsen PK (1990) Effect of a Chrysochromulina polylepis subsurface bloom on the planktonic community. Mar Ecol Prog Ser 62:21-35

Nielsen TG, Løkkegaard $B$, Richardson $K$, Pedersen FB, Hansen L (1993) The structure of plankton communities in the Dogger Bank area (North Sea) during a stratified situation. Mar Ecol Prog Ser 95:115-131

Nielsen TG, Sabatini M (1996) Role of cyclopoid copepods Oithona spp. in North Sea plankton communities. Mar Ecol Prog Ser 139:79-93

Petersson $H$ (1934) Scattering and extinction of light in seawater. Meddelanden Göteborgs Högskolas Oceanografiska Institution $4 \mathrm{~b}(4)$

Editorial responsibility: Otto Kinne (Editor),

Oldendorf/Luhe, Germany
Pingree RD, Holligan PM, Mardsell GT (1978) The effects of vertical stability on phytoplankton distribution in the summer on the northwest European shelf. Deep Sea Res 25: 1011-1028

Prieur L, Legendre L (1988) Oceanographic criteria for new phytoplankton production. In: Rothschild BJ (ed) Toward a theory of biological-physical interaction in the world ocean. Kluwer Academic Publishers, Dordrecht, p $71-112$

Richardson K (1985) Plankton distribution and activity in the North Sea/Skagerrak-Kattegat frontal area in April 1984. Mar Ecol Prog Ser 26:233-244

Richardson K, Christoffersen A (1991) Seasonal distribution and production of phytoplankton in the southern Kattegat. Mar Ecol Prog Ser 78:217-227

Richardson K, Heath MR, Pedersen SM (1986) Studies of a larval herring (Clupea harengus L.) patch in the Buchan area. III. Phytoplankton distribution and primary productivity in relation to hydrographic features. Dana 6:25-36

Riegman R, Malschaert H, Colijn F (1990) Primary production of phytoplankton at a frontal zone located at the northern slope of the Dogger Bank (North Sea). Mar Biol 105: $329-336$

Riemann B, Bjørnsen PK, Newell S, Fallon R (1987) Calculation of cell production of coastal marine bacteria based on measured incorporation of $\left({ }^{3} \mathrm{H}\right)$ thymidine. Limnol Oceanogr 32(2):471-476

Strickland JDH, Parsons TR (1972) A practical handbook of seawater analysis. Bull Fish Res Bd Can 167:1-310

Vandevelde T, Legendre L, Therriault JC, Demers S, Bah A (1987) Subsurface chlorophyll maximum and hydrodynamics of the water column. J Mar Res 45:377-396

Submitted: November 10, 1997; Accepted: March 9, 1998 Proots recelved from author(s): June 23,1998 